\title{
ESP TEACHERS IN THE WORLD OF GLOBALISATION AND HIGHER EDUCATION INTERNATIONALISATION
}

\author{
Gabriela Chmelikova, Ludmila Hurajova \\ MTF STU, Jana Bottu 25, Trnava, Slovakia \\ E-Mail: gabriela.chmelikova@stuba.sk;ludmila.hurajova@stuba.sk
}

\begin{abstract}
This paper deals with the new situation the ESP teachers have to face at Higher Educational Institutions. The authors bring an insight into the situation of ESP in Slovakia and Slovak Technical University. They also put forward that ESP teachers now have to accommodate a new role of facilitators in the internationalisation of higher educational environment using the example of their Visegrad+ Project bringing together ESP practitioners and disciplinary teachers from six countries.
\end{abstract}

Key words: ESP teachers, internationalisation, disciplinary teachers, interdisciplinary and transnational cooperation

\section{INTRODUCTION}

Regarding the language competence enhancing the employability of the graduates, it comes without doubts that it is the English language which has become the lingua franca of the international scientific communication, making thus this competence a prerequisite of being successful in the field of science and technology. This also shows that the training in language is inseparable from disciplinary teaching.

Currently, all English for Specific Purposes (ESP) teachers are aware of the fact that study of any language includes not only English itself, as the language is also a sociocultural phenomenon. Thus focus on culture is comprised in ESP courses so that the students could get within their education the 'whole package' which is then utilised and appreciated particularly when the students experience mobility at foreign universities within various exchange programmes and could thus have an encounter with the international academic environment for the first time.

Internationalisation is not a new issue; it has already been mentioned in the documents representing the Bologna Process commenting on the changes to be made, particularly in European countries. Nevertheless, it seems to be a task for language teachers that being aware of the role of the English language they have to prepare their students to meet the high requirements of the current international global job market. This is one side of the game, the other one is how to bring this internationalisation into Higher Educational Institutions.

The internationalisation is now of high attention in all EU countries. Although the internationalisation could have different meanings to different people, there is one thing they have in common: it should be the reason to reshape and change the Higher Educational 
Institutions (HEI) approach to education to meet the challenges of this century. There is no doubt that this internationalising of HEIs will be a process in which it will be ESP teachers in particular who will play one of the main role in integrating the international, as well as intercultural dimensions of teaching, and thus prepare their students for international or global job market.

\section{ESP - SitUATION IN SLOVAKIA}

If we want to speak about teaching English for Specific Purposes in Slovakia, and to understand how difficult and far it has gone in its development of syllabus design, methodology, materials preparation or test design, first we need to look back.

\subsection{Before 1989}

ESP (or LSP at the time) was understood and taught in Slovakia very specifically. The emphasis was put mainly on the Russian language; the other foreign languages were a minority at HEIs. Regarding the discussions with some older fellow teachers who taught English in Trnava or Banská Bystrica, the teaching was more or less limited - also due to the lack of available materials in English - to vocabulary, i.e. reading an article and some exercises, and in some cases only to a translation method (reading an article and translating it).

\subsection{Review of the enthusiastic ESP beginnings in 90s}

The beginnings of teaching English for Specific Purposes in the early 90s were quite promising as many eager English practitioners realized that ESP is more than specific vocabulary and were looking for some intensive trainings in the field so that their teaching at Higher Educational Institutions could be changed.

\subsubsection{Building ESP teachers network}

The development of ESP in Czechoslovakia was happy to have a massive support of two institutions - British Council (BC) and United States Information Agency (USIA). The British Council has been working in our country since 1946; however, due to political situation it was closed in 1950 and reopened in 1992. In the early 90s the British Council tried to improve the awareness of English teachers and the content of English language teaching (ELT) has shifted dramatically from workshops on classroom techniques and teaching ideas to developing courses and building ELT network of secondary school teachers and HEI teachers. Although in 1996 the former Czechoslovakia quit to exist, the support of these two institutions remained active on national basis as well.

Many English practitioners successfully passed intensive courses in how to improve their ELT/ESP teaching which comprised e.g. syllabus design, methodology, materials preparation, test design, assessment, presentations skills development, etc. These courses were organised on a regular basis in the West, Middle and East Slovakia (with three main Resource Centres based in Bratislava, Banská Bystrica and Košice), during the academic year but as summer courses as well, and the lecturers checked the assignments set to teachers. Not only did the teachers meet regularly in each of the regions and started to cooperate and build a regional network, the $\mathrm{BC}$ organised also an annual meeting of all ESP teachers who passed the courses - this meant the beginning of the Slovak ESP 
teachers' network. The cooperation has lasted for years, unfortunately, as we are speaking of the 90s, many of the English practitioners are retired now and contacts lost.

\subsubsection{ESP Conferences}

Based on built network and thanks to the support of the British Council, the idea of bringing ESP teachers from secondary and tertiary levels together was born. The first ESP Conference was organised as early as in 1994 in Banská Bystrica under the tittle Making ESP Work, the next one took place in Košice in 1996 and titled as ESP Working together and the last one titled ESP Challenges! was organised by the Department of Languages from the Slovak University of Technology, Faculty of Materials Science and Technology in Trnava in 1998.

The direct contact and meetings of secondary school teachers and HEI teachers at the conference reinforced the networks and thanks to many various contributions presented, they improved and shifted the ESP teaching to a higher level. In addition, it brought also an amount of cross-border cooperation, especially with Czech and Hungarian HEIs. Due to logical reasons (e.g. the role of language course at a secondary school and HEI), the ways of secondary school English teachers and HEI language teachers then separated. The secondary school teachers founded their own association SATE (Slovak Association of Teachers of English, in Slovak known under the name SAUA/SATE), and later on the HEI foreign language teachers founded their own association - CASAJC (Czech and Slovak Association of Language Centres in Higher Education) bringing thus together all foreign language teachers, not just those English ones. The cooperation of both groups of English teachers was fruitful and resulted e.g. in new school leaving examination format (supervised by Assoc. Prof. Jana Bérešová, and supported by the BC).

\subsubsection{ESP Projects}

In the second half of $90 \mathrm{~s}$, the focus of the BC support shifted from grant giving approach and general needs to the issues the workplaces needed at most which reflected in an adopted project approach. Adopting a project approach meant that there was a need for longer-term development of networks, institutions, and systems. The idea was to deliver the work through a series of customised projects. They were, e.g. the project supporting the development and assessment expertise among secondary teachers; project of departmental training and resources, or the project focused on improving the quality of English courses offered by the Teacher Training faculties, or the project on developing and promoting an awareness of the latest ESP trends.

ESP SPECTRUM was a journal that started in 1993 as an ESP Newsletter, Slovakia, initiated because of needs analysis carried out for Slovak HEI ESP teachers. It usually comprised about 15 contributions from various fields of teaching ESP. The journal had a large impact, at the time it was available in all Higher Educational Institutions, distributed to 50 vocational and apprentice schools in Slovakia, and sent to resource centres throughout Eastern and Central Europe.

Another project - Tertiary Teacher Development aimed at providing in-service training for ESP practitioners and promoting improved standard of the teaching of ESP in HEIs and focused on upgrading ESP at HEIs. This programme involved regular in- 
service training courses, material support, publishing of SPECTRUM Newsletter, as well as reinforcing the national network of ESP practitioners.

\subsection{Current situation}

The aforementioned insight into the history of ESP teaching in Slovakia means that it has a solid background and tradition to utilise in teaching. Yet the current situation is not so promising. Despite the Bologna Process conclusions and CEFR intentions, particularly in terms of declaring the EU inhabitants should be able to speak two foreign languages plus the language of the neighbouring country, the situation at Slovak HEIs in the field of English for Specific Purposes is not very encouraging. Many universities or other higher institutions due to "financial reasons" are closing their language centres or departments, or decreasing the load of English lessons despite the quality elaborated syllabus, remarkable experience of English language practitioners, or excellent job positions of students with good study results and English language competence.

\subsection{ESP teachers in Slovakia}

The number of English practitioners at Slovak HEIs is still reducing despite the plans and visions of the Ministry of Education, Science, Research and Sport of the Slovak Republic proclaiming the necessity of having a knowledge-based and the English language competent population of graduates. Some universities closed their language centres/ departments (e.g. Trnava University, Faculty of Law), some universities allotted their language teachers to subject-specific departments (e.g. University of Ss. Cyril and Methodius in Trnava, Faculty of Social Sciences).

Despite implementing the latest ICT, utilising communicative approach in teaching, constant developing of integrated language skills, as well as soft skills, using many practical examples in teaching, having lots of extracurricular activities, the universities (especially the technically oriented ones) suffer from low interest from the public. The number of students is decreasing, not only due to the demography, but what is more, also the ESP field is facing the lack of experienced practitioners.

\subsection{ESP reality at STU MTF}

To mention just one example, in 2008/09 academic year a very successful syllabus model of language teaching had to be adjusted to the new situation as the Faculty Management decided that English would be the only foreign language taught at STU MTF. That meant that all students who studied other languages (German, French, and Russian) in their secondary schools had to start studying new language - English. Obviously, the step was quite unfriendly and represented a shock for them, for those German or French speaking in particular, as there are quite a lot successful German and French companies in the region. Not only was the decision unfriendly, it also brought a lot of extra work for English teachers, especially at the doctoral study degree.

However, the situation gradually calmed down and the certification system of UNIcert ${ }^{\circledR}$ represented here a great help (it is a certification system for non-philological universities founded in Germany, and with the Slovak Centre in Bratislava, which is responsible for Central Europe). The STU MTF graduates practically do not have any troubles to find a good job; we can even say that some of them who are technologically or IT excellent are 
headhunted. Still, the certification of their language competence increased the graduates' marketability. For six years, we provided our students with the possibility to obtain a UNIcert $^{\circledR}$ certificate.

However, in 2015/16 academic year, the situation got even worse - within the new accreditation of Slovak universities, the load of English language lessons was reduced by a half. This means that we are no more entitled to apply for the UNIcert ${ }^{\circ}$ accreditation due to the decreased number of contact lessons. Language Department at STU MTF in Trnava was facing difficult conditions: how to struggle with the improvement of language competence within two semesters and how to possibly bridge the gap between the obligatory English language study at bachelor degree (in second year), and doctoral degree (second and third year). They have to decide how to get the best of the ESP concept developed in the early 90 s and based on the thorough needs analysis of the Faculty students' needs, wants and lacks in English language knowledge on one hand, and the requirements from industrial practice on the other hand, plus regularly upgraded due to current requirements. The English practitioners had to think how to adjust to the situation, how to change the role of an ESP teacher and not lose the position which was built in previous years.

\subsection{New roles of ESP teachers}

A good ESP teacher has his/her competence built on four pillars: solid English language competence, adequate knowledge of the related HEI disciplines, awareness of specific needs of stakeholders in question (university, students, government, job market requirements, etc.), as well as experience with cultural issues of the current international environment.

Meeting all these prerequisites, however, these days the ESP teachers have to accommodate to their new role(s):

1. They could be pioneers in interdisciplinary cooperation at their HEIs in the form of submitting projects on disciplinary cooperation. We can provide a nice experience in several common interdisciplinary projects, both on national and international basis. They are as follows:

a) Bilateral project with Serbia SK-SRB-2013-0034 titled Student on-line conferences between STU MTF (Slovakia) and FEE, University of Niš (Serbia) for the purposes of specific English language and other skills development. Principal investigator: Gabriela Chmelíková,

b) ERASMUS+ Project 2015-1-SK01-KA201-008937 titled as Transnational exchange of good CLIL practice among European Educational Institutions, involving five EU countries, responsible representative for STU MTF: L'udmila Hurajová,

c) or the current international project in Visegrad+ Scheme bringing together ESP and disciplinary teachers (DT) from Slovakia, Czech Republic, Hungary, Poland and Albania, and Serbia from the Western Balkan countries (principal investigator: L. Hurajová).

2. They could enhance the cooperation with disciplinary teachers also in the field of extracurricular activities, e.g. STU MTF example: ESP teachers cooperate with DT within the annually organised Student Research Conference.

3. They could facilitate in internationalisation of their HEI as many universities are preparing or even already offering study programmes in English. Again, an example from STU MTF ESP teachers experience, regarding the results of an institutional project looking for the preparedness of teachers for teaching in English (INTER MTF I): from the questionnaire (209 teachers addressed/100 responded) it follows that $67.3 \%$ of DTs are willing to start teaching their subject in the English language. Obviously, ESP teachers 
offered the support and facilitation in the near future. Currently, we are waiting for the results from INTER MTF II Project, which will bring the results about the preparedness of students to be taught in English.

\section{INTERNATIONALIZATION OF HIGHER EDUCATION}

The term "Internationalization of Higher Education" (IoHE) is not a new term. It has been used for several decades to describe the processes within HEIs (Higher Education Institutions) regarding the international cooperation, research, etc. The more the world has become globalized, the stronger pressure has been put on the HEIs to be a part of the globalization process. Larsen (2016, p.3) states that during the 1990s, a significant ontological shift was made from conceptualizing internationalisation as an outcome to defining it as a process. Knight (2004, p.11) defined the internationalisation at the national/sector/institutional level as "the process of integrating an international, intercultural or global dimension into the purpose, functions or delivery of post-secondary education". Larsen (2016) outlines three assumptions related to the definitions of the internationalisation process:

1) International is something external to the HEIs and needs to be incorporated into all functions of the university.

2) There is something fundamentally different between the terms international, intercultural, and global, international implies relationships between nations, and draws attention to the nation-state, intercultural implies not only relationships between cultures, but there is potential for mutual transformation within those cross-cultural relations.

3) Globalization is both external to higher education and a threat to local places, thus requiring a defensive response. Marginson and Sawir (2011) claim that internationalization is a strategy "premised not on economic profit making but on universal human rights, free cultural exchange and respect for cultural others". So, universities seem to be the right institutions to design more socially and humane globalized world with the aim at providing the international and professional environment for solving current world challenges.

The scholars dealing with IoHE distinguish between IaH (internationalisation at home) and IA (internationalisation abroad). IaH refers to the process that is being done locally within the HEI with the cultural diversity of the university and aims to develop global perspectives, cross-cultural communication skills, foreign language skills (mainly English) and intercultural competencies among all members of the university are taken into account. On the other hand, IA is about all forms of education that go beyond the limits of political/geographical borders, for example studying abroad, joint and double degree programs, branch campuses, international research collaboration, and online learning courses. In some cases, IaH and IA may overlap.

\subsection{HEI Internationalisation strategy in Europe}

As far as the internationalisation process of HEIs is concerned, COM (2013, p.3) 499 says that many HEIs already have higher education internationalisation strategies in place. However, these are often centred mainly on student mobility; international academic cooperation is often still fragmented, based on the initiative of individual academics or research teams, and not necessarily linked to an institutional or national strategy. The text continues, "Effective strategies should also include the development of international curricula, strategic partnership, finding new ways of delivering content, and ensuring 
complementarity with broader national policies for external cooperation, international development, migration, trade, employment, regional development, research and innovation". Such strategy is called "comprehensive" and there is no one-size-fits-all approach how to develop this strategy. It is recommended in COM (2013, p.4) 499 to design tailored comprehensive strategies for EU Member States to reinforce their strengths, their international presence, and attract talent. The comprehensive strategy for internationalising HEIs should cover the following areas:

1) Promoting and enhancing the international mobility of students and staff;

2) Promoting of IaT and digital learning;

3) Strengthening strategic cooperation, partnership and capacity building.

What is essential to bear in mind regarding the internationalisation process of HEIs is the diversity of context, the reason of the internationalisation process, level of linguistic and academic capital of the HEI. Buckner (2019) analyses how rationalizations of internationalisation in HEIs vary across contexts, focusing on the factors associated with referencing two particular benefits: international awareness and revenue generation. The Anglophone countries, particularly outside of North America, are more likely to interpret the term "internationalisation" in terms of revenue generation. On the other hand, both New Zealand and Australia have placed more emphasis on global citizenship as Bruckner (2019, p. 332) states. She adds that European HEIs were actually less likely to emphasize increasing students' awareness and global engagement; maybe caused by the presumption that students already have high level of international awareness.

Bruckner (2019) also indicates from the findings that the additional revenue from international students is interpreted within the study as an "opportunity" to capitalise off global demand for English. The 2018 European Barometer shows a shift in the purpose of internationalisation of HEIs - from emphasising the quality to emphasizing preparing the students for a global world, which may be due to Brexit and the rise of nationalism (Sandstrom and Hudson 2018, p.13).

\subsection{Language of the HEI Internationalization process in Europe}

As aforementioned, English is the language that is closely linked with the internationalisation process of HEIs worldwide. Many prestigious universities established in English speaking countries can generate revenue from accepting foreign students for studying. These universities are also the leads in $\mathrm{IaH}$, particularly in designing and providing both online academic courses and study programmes. On the other hand, in nonEnglish speaking countries, English is the first limit/prerequisite for the internationalization process of the HEIs. For EU Member States as it stated in the COM (2013, p. 6), English is de facto part of any internationalisation strategy for learners, teachers and institutions. The situation in EU is a bit complex, as multilingualism is a significant asset and additional language skills may widen career prospects.

Nevertheless, English is the tool needed for the process of internationalisation of the HEIs. To fulfil all areas of the comprehensive strategy for the internationalisation, the sufficient level of the English language competence is required from all stakeholders. On the contrary, many university managements decided to diminish position of ESP professionals within the HEIs by lowering number of mandatory ESP courses for students and the situation is discouraging in staff development in English. So, how to cope with the new situation for all HEIs in Europe and with the pressure on IaH and IA that is getting stronger? The solution seems to be based on cooperation. 


\section{COOPERATION IN THE WORLD OF GLOBALIZATION}

These days we face global challenges such as lack of natural resources, climate change, growing population on the Earth, lowering level of biodiversity, rapid development of artificial intelligence, hazardous human genome manipulation, etc. To sort them out, we need to cooperate as human beings to build effective working teams consisting of professionals from various fields. This is and should be the right way for HEIs to sort out the process of internationalisation. Various project programmes financed by EU, or other funds such as ERASMUS+, Horizon 2020, APVV, Visegrad, COST, etc., provide the opportunities to establish a "mini" international environment, and by gradual steps to contribute to the HEI internationalization process.

\subsection{Visegrad+ project objectives}

This paper presents the specific project "CLIL-Higher Education Teacher" (CLIL$H E T$ ) with the main aim to develop an online platform for two communities:

1) ESP/CLIL (Content and Language integrated learning) experts,

2) Disciplinary teachers (focus on teachers of technical/economical disciplines to enhance the internationalisation process of HEIs within Visegrad countries V4 (Slovakia, the Czech Republic, Hungary, Poland) and Western Balkan countries WB (Serbia, Albania).

Regarding establishing the English Education Environment (EEE), the situation of the academic courses in various disciplines at HEIs in V4/WB countries is similar. Most of the courses are provided for the students in their mother tongue/or in local state language. Most of the teachers deliver their lectures, seminars, etc., in state language, and not in English. As far as students at these HEIs are concerned, the process of setting EEE should be well and gradually prepared instead of spontaneous implementation, as they have a natural fear of studying in English. Therefore, disciplinary teachers should understand and be well prepared how to enhance students' English skills within their discipline courses. They should be aware of CLIL dual principle of teaching to set up effective EEE. We believe that cooperation among ESP/CLIL specialists operating at HEIs in V4/WB countries brings a new insight into English implementation into the education process to improve students/teachers mobility and open a platform for deeper interdisciplinary cooperation on transnational level. It might foster cross-country/cross-institutional project work.

\subsubsection{Visegrad+ project outcomes}

To achieve our project objectives we have planned four project outcomes:

1) OSDP - open source digital platform (two communities),

2) Didactic programme for disciplinary teachers - manual for English Didactics, CLIL approach, integrated teaching/learning,

3) ILWs - identification of linguistic weaknesses - test for disciplinary teachers

4) International Seminar called "ESP and CLIL - current drivers of HEI internationalisation".

Within the project, we are planning to design the didactic program for discipline teachers to assist them to set up EEE in various academic education forms. The disciplinary teachers are supposed to prepare at least four CLIL lessons (they can be taught in English partially) and record them for uploading onto OSDP. We are building a resource bank where other disciplinary teachers in EU can find the materials or inspiration for their classes 
taught in English. Didactic programme will be translated into six national languages (Slovak, Czech, Polish, Hungarian, Serbian, and Albanian) to ensure that the disciplinary teachers with lower level of English are provided the programme they can read in their mother tongue/the language they understand better. All materials will be available on www.clil-het.eu with free access to them. We also decided to identify the weaknesses of the disciplinary teachers in their English competence within the project and interpret the findings in a report. The report will be the base for the next international project with the main objective - to prepare a linguistic support programme for the disciplinary teachers to help them to become a confident fluent English speaker.

The project lasts 18 months and the lead is MTF STU. ESP/CLIL experts in the project strongly believe that CLIL might be the solution for starting the process of IaH smoothly and gradually to avoid potential obstacles, for example students' fear of being taught in English, lack of disciplinary teachers with the proficient English, lack of teaching materials, etc. Finally, an international seminar will be organised to debate the findings we have collected. The data will be analysed and interpreted. While we are working on the project outcomes, we are planning to address ESP/CLIL experts and disciplinary teachers at the universities - project partners to ask them to join the virtual communities.

\section{CONCLUSION}

Globalized world requires global citizens to be able to become a part of active teams dealing with one of the challenges we face to these days. The rapid changes within the industries, boom of technologies, artificial intelligence and others, make HEIs consider new forms of education, new content, and new form of organisation and management of the HEIs. Becoming a relevant part of HE worldwide means to enhance the internationalisation process of the HEI in two dimensions in IaH and IA. Gradual implementation of English into education/disciplines by applying the CLIL approach might be the solution for many universities in V4 and WB countries how to start establishing EEE at their HEIs. ESP experts, whose role is continuously diminishing at HEIs within V4 and WB countries, should cope with it and flexibly react to the current situation. Their role is shifting from facilitating the students to facilitating and cooperating with the disciplinary teachers to assist them to set up EEE within their courses effectively. The Visegrad+ project "CLILHigher Education Teacher" (CLIL-HET) presented above aims at developing an open source digital platform for building two virtual communities of ESP/CLIL experts and Disciplinary Teachers. The interdisciplinary cooperation between ESP/CLIL experts and Disciplinary Teachers, among ESP/CLIL experts from project partners' schools, among ESP/CLIL experts within the virtual community and among Disciplinary Teachers within their online community might lead to a simple model how to start setting up EEE at HEIs.

ACKNOWLEDGEMENT. The paper is supported by the project 015STU-4/2018 Specialised laboratory supported by multimedia textbook for subject "Production systems design and operation" for STU Bratislava. 


\section{REFERENCES}

Buckner., E. "The Internationalization of Higher education: National Interpretations of a Global Model". Comparative Education Review. Vol. 63, 2019. No. 3. 315-336. https://www.journals.uchicago.edu/doi/abs/10.1086/703794.

COM. 2013. 499 European Commission. "Communication from the commission to the European Parliament, the Council, the European Economic and Social Committee and the committee of the regions - European higher education in the world." COM (2013) 499 final

Common European Framework of Reference for Languages: Learning, Teaching, Assessment. Cambridge University Press, Cambridge, 2004. Pp. 1-8.

https://ec.europa.eu/transparency/regdoc/rep/1/2013/EN/1-2013-499-EN-F1-1.Pdf

Hurajová, L. "CLIL and its forms", in Establishing the predominant position of ESP within adult English language teaching. CSP, 2018.

Hurajová, L. "Professional Teacher Competences in CLIL," dissertation thesis, KF, Nitra, 2013, pp. 159, 104.

Jordan, R. R. English for Academic Purposes. Cambridge University Press, Cambridge, 1997. Pp. 249-257.

Knight, J. "Internationalisation remodeled:definition, approaches and rationales". Journal of Studies in International education, No.8, 2004. Pp. 5-31. https://doi.org/10.1177/ 1028315303260832

Komotar, M. H. "Comprehensive internationalization of Slovenian higher education? The rhetoric and realities." Higher Education, No. 77, 2009. Pp. 871-887. https://doi.org/ 10.1007/s10734-018-0306-6.

Larsen, A. M. Internationalization of Higher Education. An analysis through Spatial, Network, and Mobilities Theories. 2016. New York: Palgrave Macmillan.

Marginson, S., \& Sawir, E. Ideas for intercultural education. 2011. New York. Palgrave Macmillan.

Mironovová, E. Collaboration of language section with Subject.-specific Departments. In: c4, Hollenbrün, Austria, pp. 167-170, [online]. Retrieved 25 September 2017 from http:// journal.ph-noe.ac.at/index.php/resource/article/ view/.

Miština. J. et al, "Information and communication technologies in foreign language teaching," STU Bratislava. 2006.

Sandstrom, A. M., and Hudson, R. The EAIE Barometer: Internationalisation in Europe. 2018. Helsinki. $2^{\text {nd }}$ ed.. European Association for International Education (EAIE).

Scott, D. "Interdiciplinarity, Transdisciplinarity and the Higher Education Curriculum". In: Gibbs, P. et al. Transdiciplinary Higher Education. A theoretical basis Revealed in Practice. Springer International Publishing AG, 2017. Pp. 31-43.

Thompson, K. J., Interdisciplinarity. History, Theory \& Practice. Wayne State University Press, Detroit, 1990. Pp. 75-77. 